MECHANICAL FNGINFERING DIPARTMENT

BRIGITAM YOLNG WNHERSITY

$242 \mathrm{CB}$

PO BOX 24102

Provo, litaH $84602-4102$

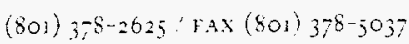

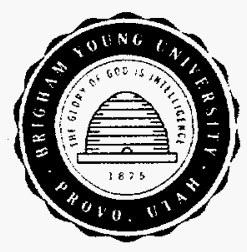

DOE/PC/95223--3

October 30, 1996

AAD Document Control

U. S. Department of Energy

Pittsburgh Energy Technology Center

P.O. Box 10940, MS 921-143

Pittsburgh, PA $15236-0940$

To Whom it May Concern:

Please find enclosed two copies of the semi annual report for contract DE-FG22-

95PC95223, entitled, "Temperature, Velocity and Species Profile Measurements for Reburning in a Pulverized, Entrained Flow Coal Reactor,"' covering the period from April 1 - September. 30, 1996. Also included is a disk containing the title page created using the Form Maker program and the report saved in Adobe Acrobat PDF format. All attempts have been made to comply with the new electronic document reporting requirements. If there are any problems, please let me know so that they may be corrected.

Sincerely,

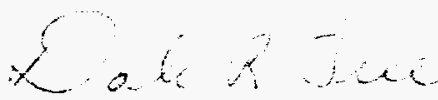

Dale R. Tree

(Assistant Professor)

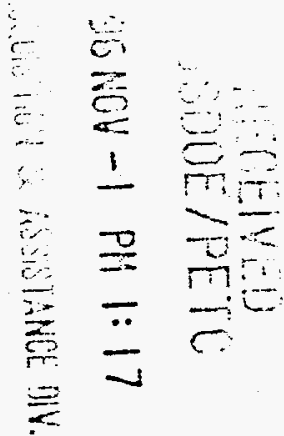




\section{DISCLAIMER}

Portions of this document may be illegible in electronic image products. Images are produced from the best available original document. 


\section{DISCLAIMER}

This report was prepared as an account of work sponsored by an agency of the United States Government. Neither the United States Government nor any agency thereof, nor any of their employees, make any warranty, express or implied, or assumes any legal hability or responsibility for the accuracy, completeness, or usefulness of any information, apparatus, product, or process disclosed, or represents that its use would not infringe privately owned rights. Reference herein to any specific commercial product, process, or service by trade name, trademark, manufacturer, or otherwise does not necessarily constitute or imply its endorsement, recommendation, or favoring by the United States Government or any agency thereof. The views and opinions of authors expressed herein do not necessarily state or reflect those of the United States Government or any agency thereof. 
Report Title:

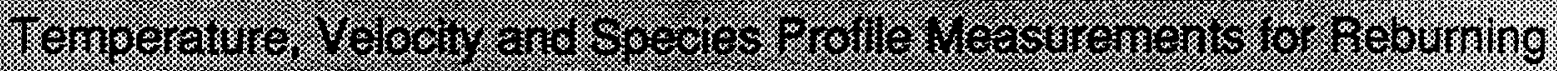

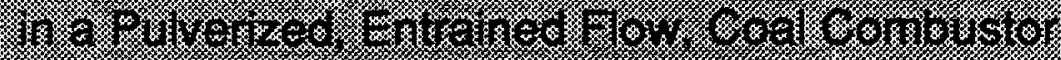

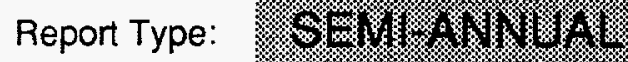

Reporting Period Start Date 04/30/1996 End Date: 10/31/1996

Principal Author(s): Dale R. Tree

Report Issue Date: $10 / 31 / 1996$

DOE Award No.: DE- FG22 -95PC95223

Submitting

Brigham Young University

Organization(s)

Name \& Address

Dale R. Tree

134 Clyde Building

Provo, UT 84602

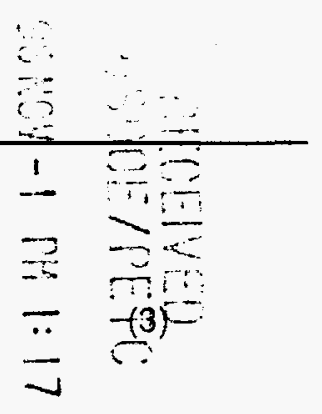

(4) 


\section{Disclaimer}

This report was prepared as an account of work sponsored by an agency of the United States Government. Neither the United States Government nor any agency thereof, nor any of their employees, makes any warranty, express or implied or assumes any legal liability or responsibility for the accuracy, completeness, or usefulness of any information apparatus, product or process disclosed or represents that its use would not infringe privately owned rights. Reference herein to any specific commercial product, process or service by trade name, trademark, manufacturer, or otherwise does not necessarily constitute or imply its endorsement, recommendation or favoring by the United State Government or any agency thereof. 


\begin{abstract}
The capability of LDA measurements for future reburning experiments has now been demonstrated. Measurements of mean and turbulent gas and particle velocity have been obtained using Laser Doppler Anemometry (LDA) in the near burner and quarl region of the pulverized coal reactor. The mean and turbulent velocity at the burner outlet, or top of the quarl were obtained under non-reacting conditions in order to obtain realistic boundary conditions for comprehensive combustion modeling. Also, under cold flow it was determined that little error occurred in measuring mean velocities with LDA using pulverized coal as the seed particle. Thus, for mean velocities, coal particle and gas velocities were similar. Coal particle velocity profiles were obtained at three swirls and three axial locations. Gas species, and temperature maps for the reactor have now also been completed at three swirl settings in addition to the LDA data. Gas species obtained include $\mathrm{CO}, \mathrm{CO}_{2}, \mathrm{O}_{2}$ and $\mathrm{NO}$. Calibration of the $\mathrm{HCN}$ and $\mathrm{NH}_{3}$ measurement has been successfully completed but no measurements in the reactor have been obtained. The design and fabrication of fuel and air injectors to be used for reburning are complete. The injectors have not yet been tested.
\end{abstract}




\title{
TEMPERATURE, VELOCITY AND SPECIES PROFILE MEASUREMENTS FOR REBURNING IN A PULVERIZED, ENTRAINED FLOW, COAL COMBUSTOR
}

Grant Number DE-FG22-95PC95223

\author{
Brigham Young University
}

Grant Date: September 1, 1995

Completion Date: August 31, 1998

\author{
Program Manager \\ Franklin Shaffer \\ Principle Investigator \\ Dale R. Tree \\ Contracting Officers Representative (COR) \\ Franklin Shaffer
}

Reporting Period

April 1, 1996 - September 30, 1996

U.S./DOE Patent Clearance is not required prior to the publication of this document. 
Table of Contents

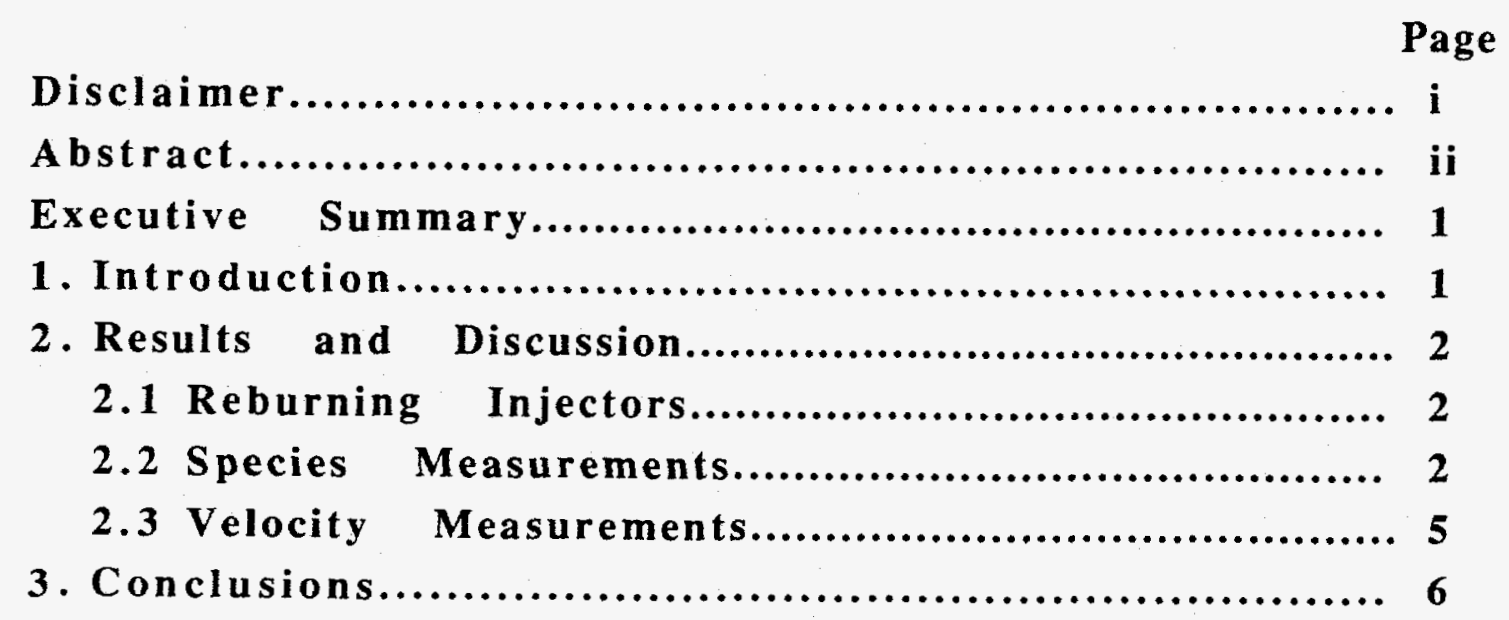




\section{Executive Summary}

The purpose of this research is to obtain detailed measurements of a reburning and advanced reburning combustion process for use in evaluating a comprehensive combustion sub-model. The first phase of this project is to obtain baseline data and tune the comprehensive model (PCGC -3) to produce a temperature, velocity and equilibrium species concentration result which agrees with the observed data. The second and third phases are to repeat this process under reburning and advanced reburning conditions and then apply the reburning and advanced reburning models respectively to compare them with the measured NO concentrations. Turbulence intensity or mixing of the reburning fuel with the combustion products is thought to be of great importance in addition to the kinetics of the reburning model in understanding the reburning process in real systems.

During the last six months the majority of the first phase objectives have been completed. The baseline data collection of gas species, temperature and velocity have been obtained. The comprehensive model has been compared with this data but to date, poor agreement has been observed and attempts to force the model to match the data have not been successful. The differences between the model and measurements appear to be due primarily to the turbulence model which can not successfully describe the flow field. Future efforts to force agreement in the model will attempt to use a combined FLUENT, PCGC-3 version of the combustion code which incorporates a more sophisticated turbulence model. Reburning measurements will begin in early November as fabrication of the apparatus for reburning experiments is now complete and ready for testing. Design of the advanced reburning system is underway.

\section{Introduction}

This report will focus on the progress and results obtained to date on the reburning injectors and the baseline data. A summary of the baseline which has been obtained is given in Table 1. At this point the baseline data set is assumed to be complete. The table shows that temperature, velocity and species data have been obtained at the three swirl settings of $0,0.5$ and 1.5. Data at swirls of 0.25 and 1.0 will no longer be pursued because behavior and trends observed at the other three swirl settings are sufficient to describe the nature of the flame. These data have been valuable in understanding the combustion process and flame structure in the controlled profile reactor (CPR) and as will be discussed, suggest the location where reburning gasses should be injected.

TABLE 1. Summary of Reactor Data taken to date.

\begin{tabular}{|l|c|c|c|c|c|}
\hline & Swirl=0. & Swirl =.25 & Swirl =0.5 & Swirl =1.0 & Swirl =1.5 \\
\hline $\begin{array}{l}\text { Temperature } \\
\text { Symmetry }\end{array}$ & $\mathrm{X}$ & $\mathrm{X}$ & $\mathrm{X}$ & $\mathrm{X}$ & $\mathrm{X}$ \\
\hline Temperature Profile & $\mathrm{X}$ & $\mathrm{X}$ & $\mathrm{X}$ & & $\mathrm{X}$ \\
\hline Mean Velocity & $\mathrm{X}$ & $\mathrm{X}$ & $\mathrm{X}$ & $\mathrm{X}$ & $\mathrm{X}$ \\
\hline Turbulent Velocity & $\mathrm{X}$ & & $\mathrm{X}$ & & $\mathrm{X}$ \\
\hline Species Profile & $\mathrm{X}$ & & $\mathrm{X}$ & & $\mathrm{X}$ \\
\hline Effluent Species & $\mathrm{X}$ & $\mathrm{X}$ & $\mathrm{X}$ & $\mathrm{X}$ & $\mathrm{X}$ \\
\hline
\end{tabular}




\section{Results and Discussion}

\subsection{Reburning Injectors}

The design and fabrication of the reburning and tertiary air injectors has been completed. The injector assembly consists of concentric tubes leading to a pintle type nozzle as shown in Figure 1. A water jacket runs between the tubes to provide cooling. The orifice of the pintle opening is adjustable to provide the ability to vary gas velocity. The injectors are to be mounted with the center of the nozzle placed in the center of the reactor and are intended to preserve the axisymmetrical nature or the reactor. The gas jet is expected to penetrate outward in an inverted conical shape and collapse inward toward the center creating a recirculation zone above the injector. The tertiary air injector is of the same design. The injectors are now ready for testing in the CPR. Compressed natural gas tanks have been installed and gaseous fuel and air metering systems are in place.

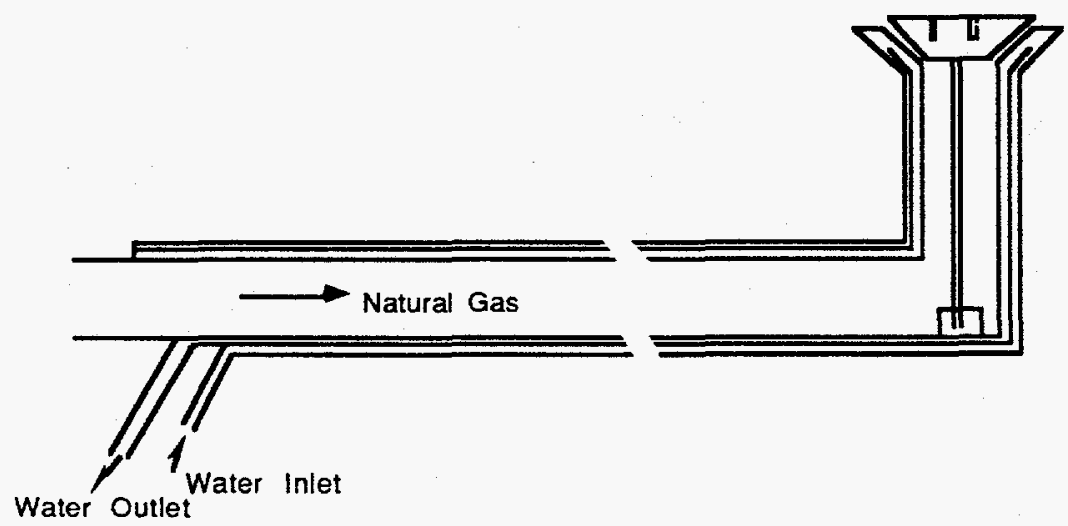

Figure 1. Natural gas and tertiary air injectors.

\subsection{Species Measurements}

Species profile maps have been completed for three swirl numbers and four species. Mapping of the concentrations of $\mathrm{O}_{2}, \mathrm{CO}_{2}, \mathrm{CO}$, and $\mathrm{NO}_{\mathrm{x}}$ has been done at swirl numbers of $0,0.5$, and 1.5. The species, temperature and velocity profiles provide an excellent detailed explanation of the reactor flame shape as a function of swirl number. Recalling from the previous semi-annual report in April, 1996, previous measurements in the CPR and reported measurements from other burners of similar design showed a significant change in flow pattern as a function swirl number. At zero swirl the flow was expected to be downward and recirculating outward toward the wall and then up along the wall. At high swirl, 1.5, the flow was expected to be directed outward at the top, down the wall and recirculating up the center of the reactor. Theses flow patterns are confirmed in the species and velocity data and help explain the trends in effluent $\mathrm{NO}_{\mathrm{x}}$.

As reported in the April 1996 semi-annual report, the effluent $\mathrm{NO}_{\mathrm{x}}$ concentrations are somewhat higher (on the order of $200 \mathrm{ppm}$ ) for the 0 and 0.5 swirl cases than for the 1.5 swirl. This is also evident in the detailed mappings of $\mathrm{NO}_{\mathrm{x}}$ which are shown in Figure 2 . These data indicate that while the peak $\mathrm{NO}_{\mathrm{x}}$ concentrations for all three swirl cases are of about the same levels (700 to $750 \mathrm{ppm}$ ) the peak in the 1.5 swirl case is a localized annular region with the $\mathrm{NO}_{\mathrm{x}}$ concentrations dropping down to near the $500 \mathrm{ppm}$ level in the 
effluent. In contrast to the 1.5 swirl case, both of the two lower swirl cases ( 0 and 0.5$)$ see the peak $\mathrm{NO}_{\mathrm{x}}$ levels in the effluent. The $\mathrm{NO}_{\mathrm{x}}$ data suggests a reduction in $\mathrm{NO}_{\mathrm{x}}$ at high swirl due possibly due to a fuel rich recirculation zone. This is confirmed by looking at the oxygen concentrations.
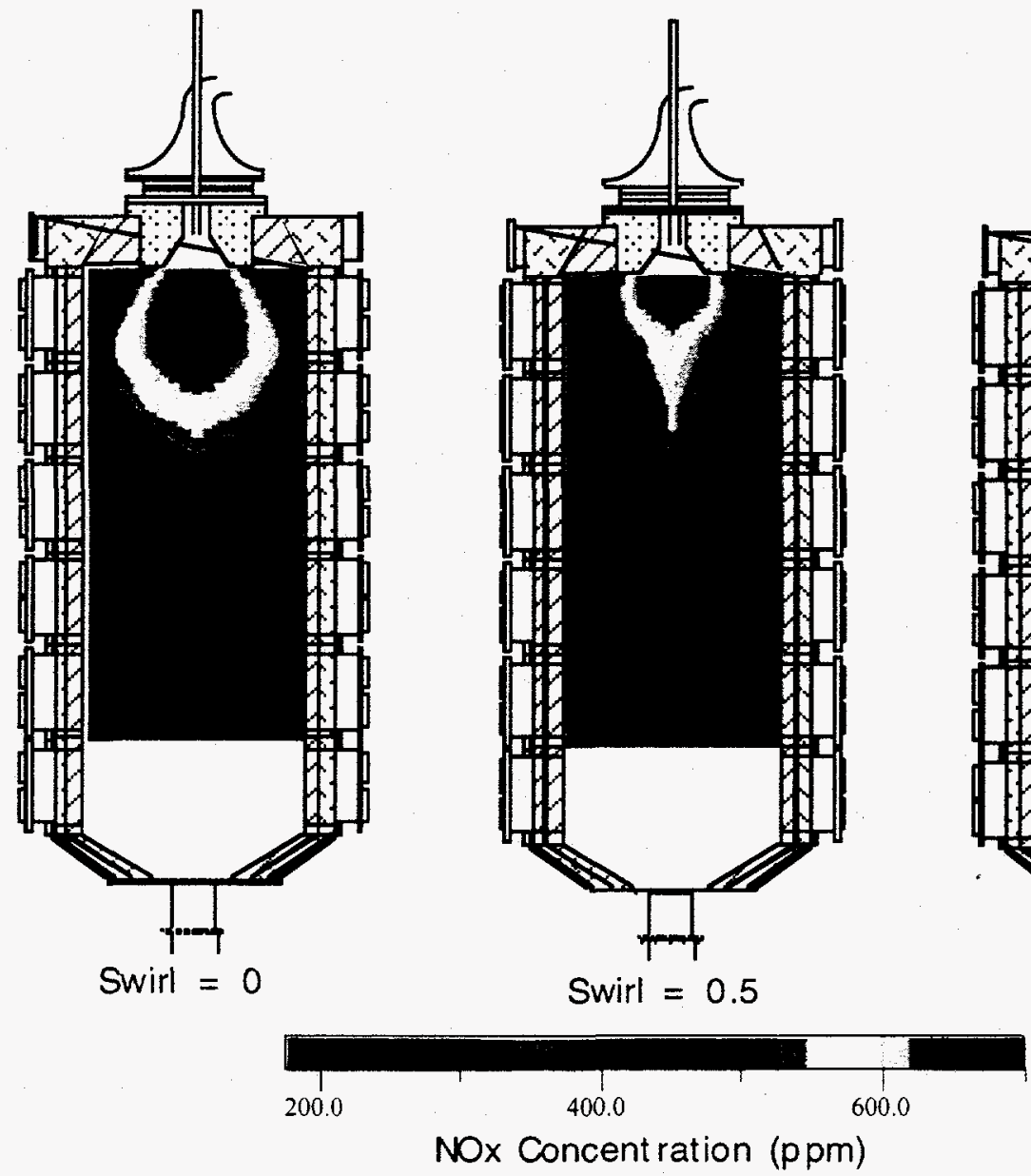

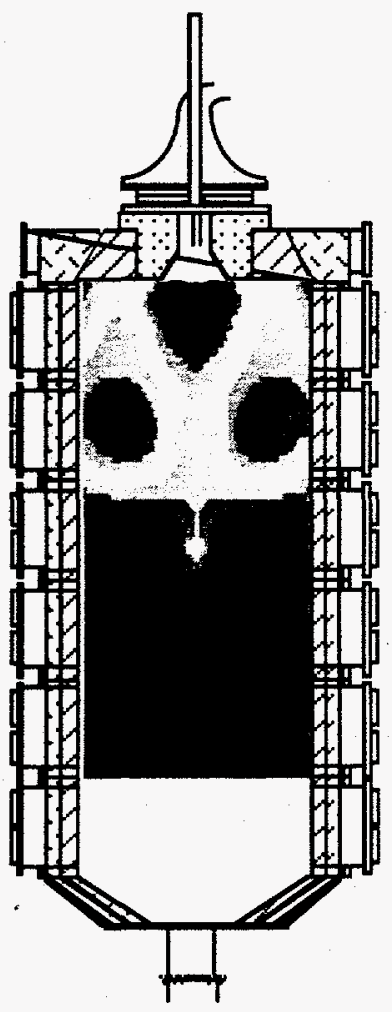

Swirl $=1.5$

Figure 2. $\mathrm{NO}_{x}$ concentrations at $0,0.5$ and 1.5 swirl.

In Figure 3, which includes $\mathrm{O}_{2}$ concentrations for all three swirls, a rather large envelope of high $\mathrm{O}_{2}$ concentration (above 10\%) is evident for the 0 swirl case. This envelope of high $\mathrm{O}_{2}$ extends about $1 / 4$ of the way down the reactor resulting in an elongated flame with a temperature of over $1500 \mathrm{~K}$ extending well below the mid point of the reactor. As the swirl increases to 0.5 the flame is pulled up towards the top of the reactor, which is dramatically demonstrated by the shrinkage of the high $\mathrm{O}_{2}$ concentration envelope for the 0.5 swirl case when compared to the 0 swirl case. Near the inlets the mean flow turns radially outward more rapidly as the swirl increases. This trend continues as the swirl is increased to 1.5 , however a fundamental change in the flow pattern has obviously taken place between swirl 0.5 and 1.5. The very high $\mathrm{O}_{2}$ concentration (greater than $15 \%$ ) zone has now split, indicating a dead or reversed flow region that extends up to the highest level data was taken just below the quarl outlet. The $\mathrm{NO}_{\mathrm{x}}$ (Figure 2) data also shows this type of a split flow pattern. 
For the 1.5 swirl case the flow appears to be turning very rapidly coming out of the primary and secondary inlets. The majority of the airflow then proceeds radially outward along the top of the reactor, turns downward at the wall for approximately $60 \mathrm{~cm}$, and then turns inward. At this point some of the flow recirculates up the centerline while the rest proceeds down and out of the reactor. The $\mathrm{NO}_{\mathrm{x}}$ concentration peaks near the turning point where some of the flow splits off into the recirculation region. The higher $\mathrm{NO}_{\mathrm{x}}$ appears to be entrained in the recirculating air, and is effectively reduced (from about $700 \mathrm{ppm}$ to 500 $\mathrm{ppm}$ ) by what appears to be a fuel rich zone in the center of the reactor. It is proposed that this fuel rich zone is caused by larger coal particles that can't make the abrupt turn as the flow exits the inlet region. These particles can penetrate to some extent the recirculation zone or are forced just slightly outward from this zone, and being larger, they take longer to devolatilize resulting in a fuel rich zone in the mid portion which tends to reduce the $\mathrm{NO}_{\mathrm{x}}$ as it enters that zone.
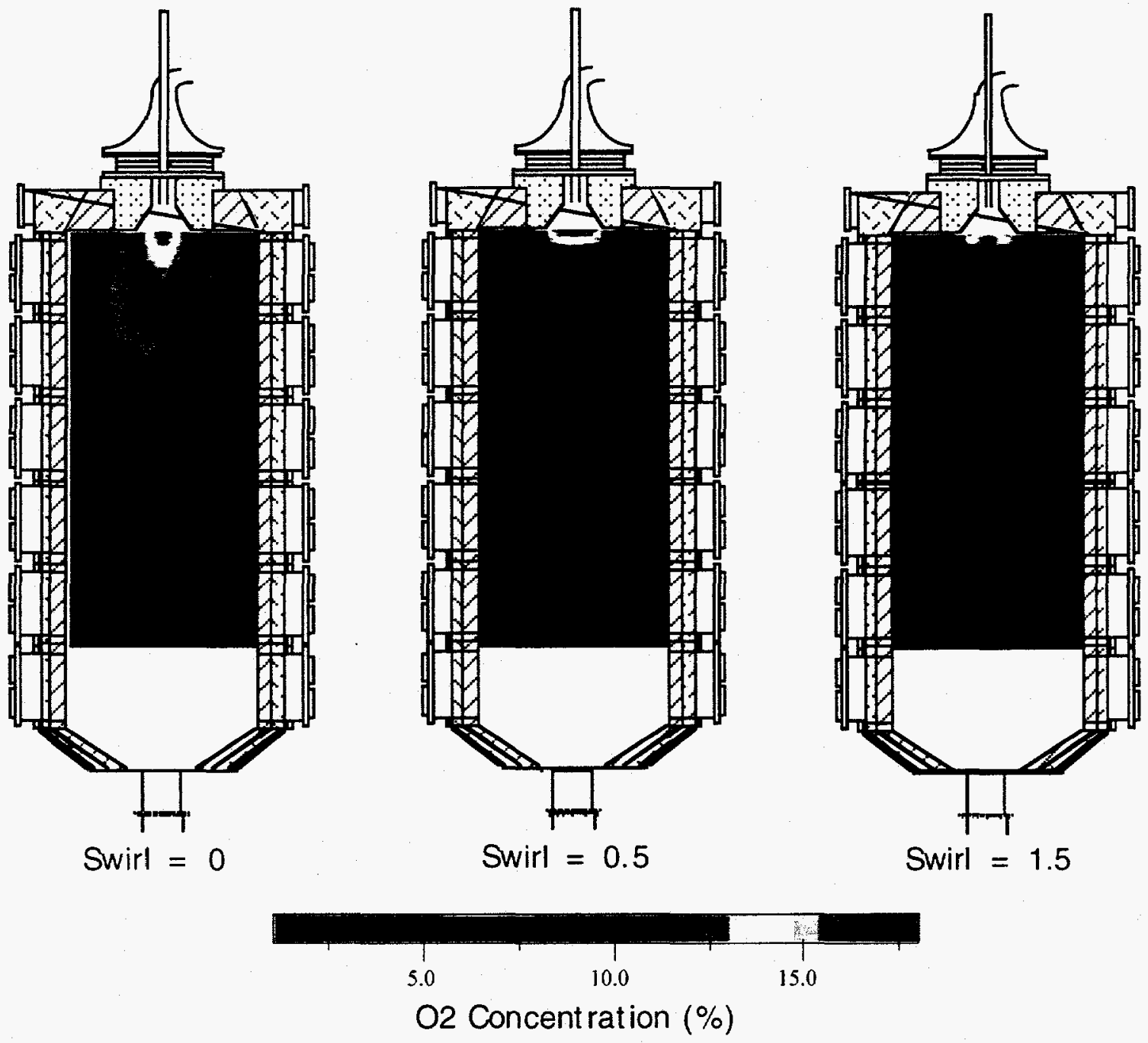

Figure 3. Oxygen concentration at $0,0.5$ and 1.5 swirl. 


\subsection{Velocity Measurements}

Laser Doppler Anemometry (LDA) velocity measurements of axial and tangential mean and RMS velocities have been successfully made in a coal flame at $0,0.5$, and 1.5 swirl. The LDA measurements were made in back scatter mode with optics set up on a table that could be moved across a radial profile of the reactor. The table height was adjusted so that measurements could be made at several axial locations. Multiple data points were collected at each location to express the average and the amount of fluctuation (RMS velocity) at that location. LDA measures the velocity of particles in the gas flow field and so there is likely some difference between the velocity of the particles and the gas phase if the particles are large. A study with several different sized particles, including coal, has shown that the expected velocity slip between the gas phase and the particles is small.

The average axial velocity for 0 and 1.5 swirl are shown in Figure 4 . The arrow direction indicates which way the flow is going relative to the reactor. At 0 swirl the velocity profile shows a central jet penetrating through the middle of the reactor with a recirculation zone towards the wall. At 1.5 swirl a definite central recirculation zone is now in place. The axial flow broadens at lower axial locations while an additional recirculation pattern forms towards the wall of the reactor. Velocity measurements at $80 \mathrm{~cm}$ at 1.5 swirl show that the primary flame region and distinct flow field have decayed by this point. This is encouraging because reburning injection, which works best if downstream of the primary flame, will be attempted near this location. Of the three axial locations LDA measurements were obtained most easily at the $80 \mathrm{~cm}$ location. This is also encouraging if further velocity measurements are desired in the reburning zone, since information about the flow field and turbulent mixing in this region would be extremely valuable.

The LDA data corresponds well with temperature and gas species data previously obtained. For example, regions of central recirculation indicated by the LDA measurement have similar temperatures. This is caused by recirculating burned gases with similar properties at these locations. Oxygen measurements at $1.5 \mathrm{swirl}$ are highest at the $24 \mathrm{~cm}$ axial location at a $10 \mathrm{~cm}$ radius, where velocity data shows the main axial jet. Towards the wall, the oxygen concentration is low which corresponds to the recirculation zone toward the wall identified with LDA.

Along with data obtained in the coal flame, an extensive map of boundary condition velocities at the swirl generator exit has also been performed with LDA. The velocities show distinct transitions in the flow as swirl is changed that directly affect the flame shape. In addition, turbulence information obtained at the boundary has been useful in making improvements in model predictions. It is expected that this information will be beneficial to turbulence model evaluation and agreement with measured data. 

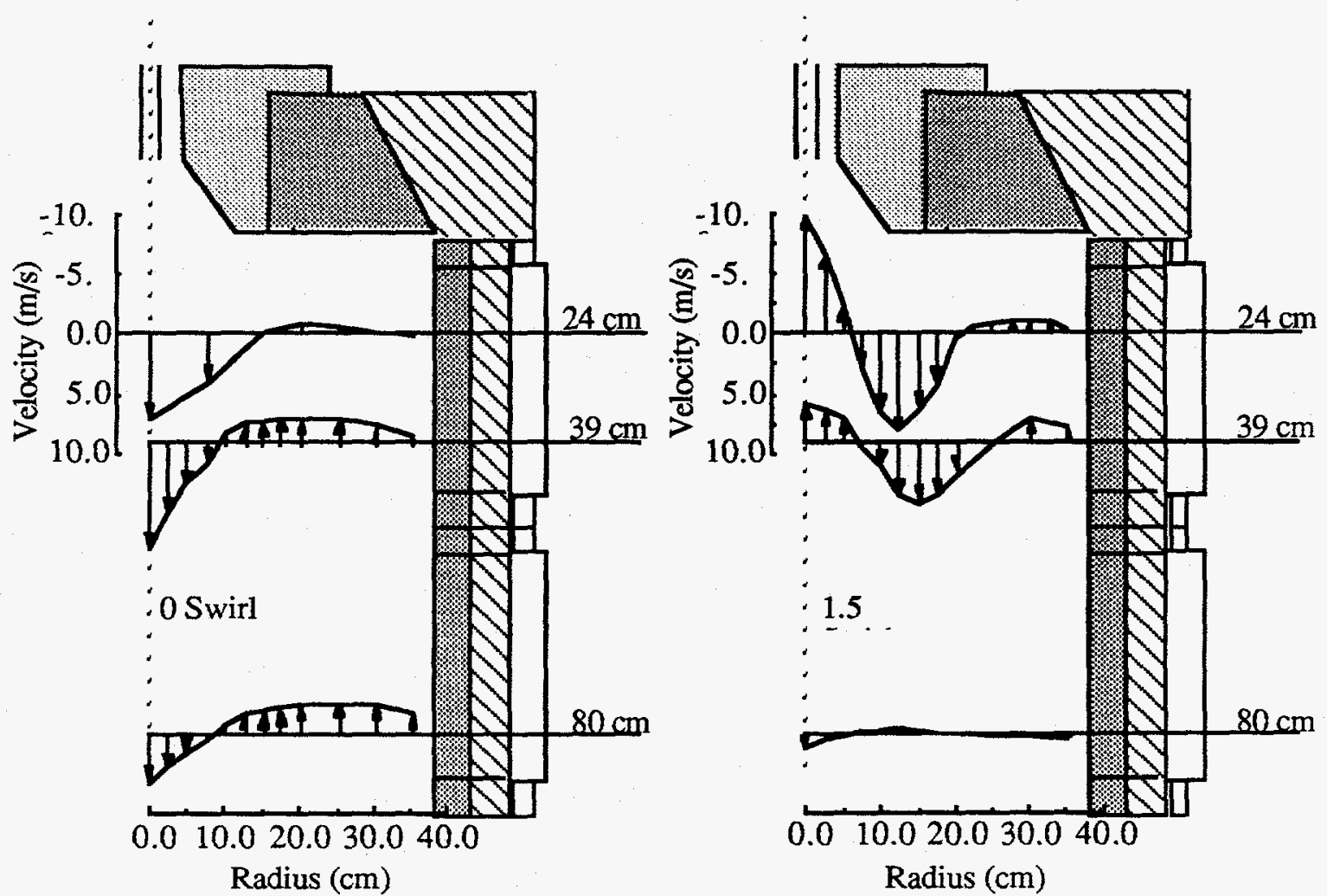

Figure 4. Axial velocity profiles obtained from LDA using coal as the seed particles at 0 and 1.5 swirl.

\section{Conclusions}

Temperature, velocity, and equilibrium species measurements have been obtained for three swirl settings in the CPR. The data are self consistent, establishing the shape and nature of the pulverized coal flame. The locations and conditions to be used for initial reburning tests have been identified. A complete set of data including velocity has been obtained for model evaluation. The velocity data has been helpful in evaluating the accuracy and problems with the existing combustion model. The gas species and velocity data can be used to explain the current trends in effluent $\mathrm{NO}_{\mathrm{x}}$. 